\title{
Mortality experience of haematite mine workers in China
}

\author{
S Y Chen, R B Hayes, S R Liang, Q G Li, P A Stewart, A Blair
}

\begin{abstract}
The mortality risk of iron ore (haematite) miners between 1970 and 1982 was investigated in a retrospective cohort study of workers from two mines, Longyan and Taochong, in China. The cohort was limited to men and consisted of 5406 underground miners and 1038 unexposed surface workers. Among the 490 underground miners who died, $205(42 \%)$ died of silicosis and silicotuberculosis and $98(20 \%)$ of cancer, including 29 cases (5.9\%) of lung cancer. The study found an excess risk of non-malignant respiratory disease and of lung cancer among haematite miners. The standardised mortality ratio for lung cancer compared with nationwide male population rates was significantly raised $(S M R=3 \cdot 7)$, especially for those $\mathrm{min}$ ers who were first employed underground before mechanical ventilation and wet drilling were introduced $(S M R=4.8)$; with jobs involving heavy exposure to dust, radon, and radon daughters $(S M R=4 \cdot 2)$; with a history of silicosis (SMR = 5.3); and with silicotuberculosis (SMR = 6.6). No excess risk of lung cancer was observed in unexposed workers (SMR = 1·2). Among current smokers, the risk of lung cancer increased with the level of exposure to dust. The mortality from all cancer, stomach, liver, and oesophageal cancer was not raised among underground miners. An excess risk of lung cancer among underground mine workers which could not be attributed solely to tobacco use was associated with working conditions underground, especially with exposure to dust and radon gas and with the presence of non-malignant respiratory disease. Because of an overlap of exposures to dust and radon daughters, the independent effects of these factors could not be evaluated.
\end{abstract}

\footnotetext{
Institute of Occupational Medicine Chinese Academy of Preventive Medicine, Beijing, People's Republic of China

S Y Chen, S R Liang, Q G Li

Epidemiology and Biostatics Program, US National Cancer Institute, Bethesda, MD, USA

R B Hayes, P A Stewart, A Blair
}

Several epidemiological studies from the United Kingdom, Sweden, France, and the USSR have shown associations between haematite mining and lung cancer. ${ }^{1-12}$ One large study of haematite miners from the United States did not show an excess risk for lung cancer. ${ }^{13}$ Recently, in a mortality study of haematite miners in Cumbria followed up from 1939 to 1982 Kinlen found no excess risk for lung cancer. ${ }^{14}$ In a previous study from 1948 to 1967 in these mines an excess of lung cancer was found. ${ }^{2}$ Kinlen indicated that the risk for lung cancer in these mines had largely disappeared in recent years with the introduction of improved industrial hygiene measures. Most of these surveys suggested that the increased risk of lung cancer is generally attributed to exposure to radon gas. In China we undertook a retrospective cohort study to assess the risk of lung cancer among employees at two haematite mines, Longyan mine in Hebei province and Taochong mine in Anhui province. Limited environmental monitoring data and information on work history and cigarette use of study members were available.

\section{Materials and methods}

EXPOSURE ASSESSMENT

The ore mined at Longyan and Taochong has been predominantly haematite. Mining has been carried out at Longyan mine since 1917 and at Taochong mine since the 1940s. The potential for exposure has changed with the modification of mining procedures. The introduction of mechanical ventilation and wet drilling at the Longyan mine in 1955 and the Taochong mine in 1963 reduced the concentration of total airborne dust, measured gravimetrically, from several hundred $\mathrm{mg} / \mathrm{m}^{3}$ to less than $10 \mathrm{mg} / \mathrm{m}^{3}$ on average. Monitoring data from Longyan mine from 1971 to 1979 found average dust concentrations of $3.8 \mathrm{mg} / \mathrm{m}^{3}\left(\mathrm{n}=4655 ; 1.8-9.2 \mathrm{mg} / \mathrm{m}^{3}\right)$ for mining and drilling operators and $2.7 \mathrm{mg} / \mathrm{m}^{3}(\mathrm{n}=167 ; 1.2-$ $3.0 \mathrm{mg} / \mathrm{m}^{3}$ ) for loading machine operators.

During the period of the present survey, environmental measurements were made for chemical elements in settled dust by plasma spectrography, for 3,4-benzo[a]pyrene (BaP) by high performance liquid chromatography, and for radon and radon daughter content. In Longyan mine $28 \%$ of the settled dust and in Taochong mine $23 \%$ of the settled dust was iron. Titanium was found at greater than 
Table 1 Environmental levels of radon and radon daughters in air in Longyan and Taochong haematite mines, 1984

\begin{tabular}{|c|c|c|c|c|c|c|}
\hline \multirow[b]{2}{*}{ Mine } & \multirow{2}{*}{$\begin{array}{l}\text { No of } \\
\text { samples }\end{array}$} & \multicolumn{2}{|l|}{ Radon } & \multicolumn{2}{|c|}{$\begin{array}{l}\text { Radon: daughters } \\
\text { potential energy }\end{array}$} & \multirow{2}{*}{$\begin{array}{l}\text { Annual effective } \\
\text { dose equivalent } \\
(m S v)\end{array}$} \\
\hline & & $B q m^{-3}$ & $\overline{p C i / l}$ & $10^{-8} \mathrm{Jm}^{-3}$ & $W L$ & \\
\hline \multicolumn{7}{|c|}{ Longyan mine } \\
\hline $\begin{array}{l}\text { Underground: } \\
\text { Working face } \\
\text { Other areas } \\
\text { Air being exhausted from underground } \\
\text { Air entering underground } \\
\text { Above ground }\end{array}$ & $\begin{array}{r}38 \\
13 \\
22 \\
2 \\
1 \\
3\end{array}$ & $\begin{aligned} 1028 & \pm 594 \\
1329 & \pm 559 \\
808 & \pm 464 \\
1930 & \pm 14 \\
60 & \\
19 & \pm 0\end{aligned}$ & $\begin{array}{r}27 \cdot 8 \\
35 \cdot 9 \\
21 \cdot 8 \\
52 \cdot 2 \\
1 \cdot 6 \\
0 \cdot 5\end{array}$ & $\begin{aligned} 317 & \pm 232 \\
442 & \pm 267 \\
260 & \pm 189 \\
270 & \pm 155 \\
21 & \\
3 & \pm 0\end{aligned}$ & $\begin{array}{l}0 \cdot 2 \\
0 \cdot 2 \\
0 \cdot 1 \\
0 \cdot 1 \\
0 \cdot 0 \\
0 \cdot 0\end{array}$ & 21 \\
\hline \multicolumn{7}{|c|}{ Taochong mine } \\
\hline $\begin{array}{l}\text { Underground: } \\
\text { Workface } \\
\text { Other areas }\end{array}$ & $\begin{array}{l}32 \\
15 \\
17\end{array}$ & $\begin{array}{l}1479 \pm 1338 \\
1519 \pm 946 \\
1402 \pm 1544\end{array}$ & $\begin{array}{l}40 \cdot 0 \\
41 \cdot 1 \\
37 \cdot 9\end{array}$ & $\begin{array}{l}428 \pm 634 \\
405 \pm 382 \\
449 \pm 801\end{array}$ & $\begin{array}{l}0 \cdot 2 \\
0 \cdot 2 \\
0 \cdot 2\end{array}$ & 30 \\
\hline $\begin{array}{l}\text { Standard occupational limit } \\
\text { Standard residential limit }\end{array}$ & & 3700 & $100 \cdot 0$ & 640 & 0.3 & $\begin{array}{r}50 \\
5\end{array}$ \\
\hline
\end{tabular}

trace levels, $0 \cdot 1 \%$ for Longyan mine and $0.04 \%$ for Taochong, whereas only traces $(<0.01 \%)$ were found of the 25 other elements measured, including arsenic, chromium, nickel, cobalt, cadmium, and beryllium. The level of airborne $\mathrm{BaP}$ in the mines was generally low, with only occasional measurements beyond the maximum allowable concentration for occupational exposure $\left(0 \cdot 15 \mu \mathrm{g} / \mathrm{m}^{3}\right) .^{15}$ The average of $\mathrm{BaP}$ for Taochong mine was $0.08 \mu \mathrm{g} / \mathrm{m}^{3}$ (n=6; $\left.0.015-0.36 \mu \mathrm{g} / \mathrm{m}^{3}\right)$ and for Longyan $0.03 \mu \mathrm{g} / \mathrm{m}^{3}$ ( $\mathrm{n}=7 ; 0.007-0.16 \mu \mathrm{g} / \mathrm{m}^{3}$ ). Concentrations among medium and heavy dust exposed workers in the two mines corresponded to $\mathrm{BaP}$ values of $0.04(\mathrm{n}=4)$ and $0.07=\mathrm{g} / \mathrm{m}^{3}(\mathrm{n}=6)$.

Table 1 shows the air levels of radon and radon daughters in the two mines in 1984. The annual effective dose equivalent ( $\mathrm{mSv}$ ) based on potential energy, breathing velocity $\left(1.2 \mathrm{~m}^{3} / \mathrm{h}\right)$ and annual working time (2000 hours) for underground miners was lower than the allowable occupational limit for one year for related mines classified as having radiation exposure $(\mathrm{mSv}=50)$, but was about fourfold higher than those recommended for residential exposure $(\mathrm{mSv}=5)$ in China. ${ }^{16}$ The concentration of radon $\left(\mathrm{Bgm}^{-3}\right)$ and radon daughters $\left(\mathrm{Jm}^{-3}\right)$ under- ground (1028 $\mathrm{Bgm}^{-3}$ and $\left.317 \times 10^{-8} \mathrm{Jm}^{-3} ; \mathrm{n}=38\right)$ in Longyan mine was much higher than the above ground concentration $\left(19 \mathrm{Bgm}^{-3}, 3 \times 10^{-8} \mathrm{Jm}^{-3}\right.$; $\mathrm{n}=3$ ). The air entering the underground mine was $60 \mathrm{Bgm}^{-3}$ and $21 \times 10^{-8} \mathrm{Jm}^{-3} \mathrm{n}=1$, respectively, for radon and its daughters, whereas the air being exhausted from the mine $(\mathrm{n}=2)$ was 32 -fold higher for radon and 13-fold higher for radon daughters. The level of radon and radon daughters at the working face was higher than at other areas underground. The calculation for low, medium, and heavy dust exposure, although based on few samples, indicated that the radon concentrations approximately paralleled dust exposure (table 2).

The study cohort was grouped by job title into unexposed and low, medium, and heavily dust exposed workers. The unexposed group consisted of above ground workers including office staff, non-ore transport workers, and electricians and mechanics who do not go underground. Workers, based on the job held for the longest period of time underground, with low exposure had jobs underground such as safety worker, ventilation worker, and storekeeper. Workers with medium exposure had jobs such as loading machine operator, conveyor operator, elec-

Table 2 Exposures and SMRs for lung cancer at Longyan mine. (Number in parentheses refers to number of samples)

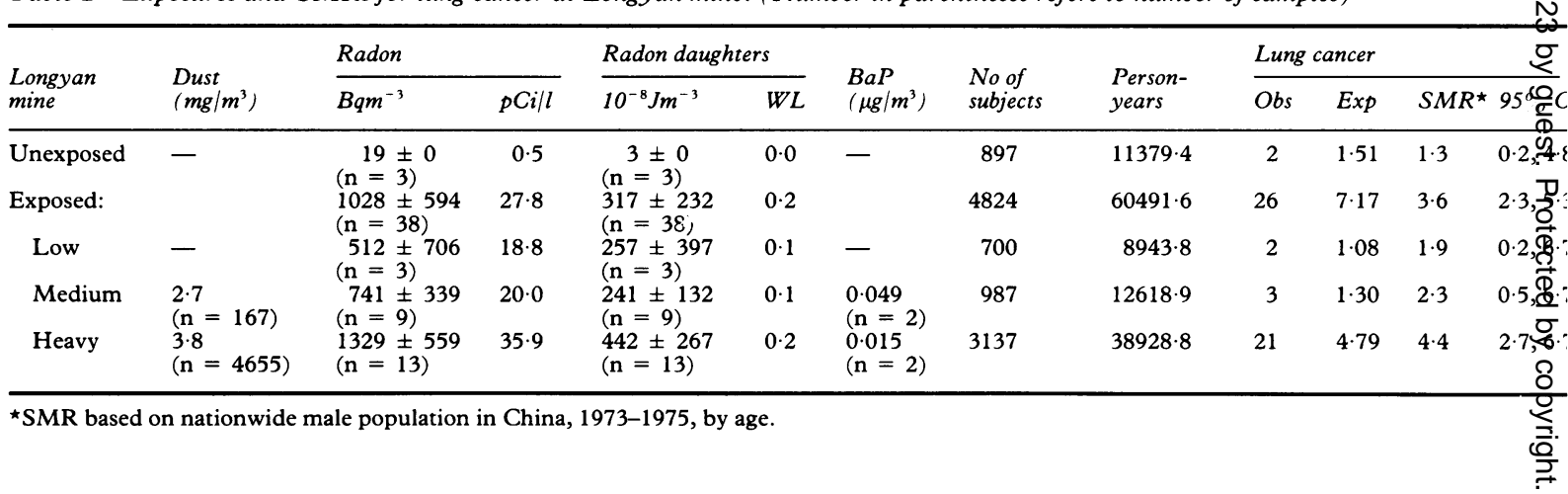


tric train operator, and track maintenance. Heavily exposed workers were all directly involved in drilling and mining at the mine face.

\section{STUDY POPULATION}

Personnel files of the two mining companies were reviewed and 8641 men were identified who were employed on 1 January 1970. Vital status on 31 December 1982 was determined by individual tracing interviews and, when necessary, by mailed questionnaire to subjects or next of kin. Vital status was ascertained for $8534(99 \%)$ of the study subjects. The 107 people lost to follow up were excluded from the study.

Information on occupational history at the mines, personal health conditions, and smoking habits were obtained by questionnaire from the study subjects or, if dead, from next of kin. For the present analysis, we excluded $2090(24 \%)$ workers as ineligible for study: those who had been employed at the mines for less than one year before 1 January 1970; who had worked in taconite $\left(\mathrm{Fe}_{3} \mathrm{O}_{4}\right)$ mining; or who, based on job title, had been exposed to silica dust above ground. This last exclusion was made to create a group of above ground workers not exposed to silica. By these criteria, 6444 subjects (Longyan mine $=5721$, Tachong mine $=723$ ), including 1308 non-exposed above ground and 5406 underground exposed miners (low exposure $=772$, medium exposure $=1197$, heavy exposure $=3437$ ) were included for study.

Cause of death was generally obtained from the records of the pension department. For deaths from cancer, hospital medical records were reviewed to verify the primary site of the tumour and to determine the methods used for diagnosis, relying on the criteria for malignant tumour investigation in China. ${ }^{17}$ Causes of death were recorded according to the ninth revision of the International Classification of Disease. ${ }^{18}$

In China routine physical examinations including a chest radiograph have been offered since 1963 on an annual or semiannual basis to mine workers. According to criteria for diagnosis established in China in $1963,1335(24 \cdot 7 \%)$ of the study group mine workers were diagnosed as having silicosis by review panels of specialists in occupational medicine and radiology. Of these silicotic subjects, $560(42 \%)$ were diagnosed as having silicotuberculosis. Of the 4071 nonsilicotic subjects, only seven $(0.2 \%)$ had tuberculosis.

\section{STATISTICAL METHODS}

For the statistical analysis, person-years were accumulated from the study entry date (1 January 1970) until the date of death or 31 December 1982, whichever occurred first. Age adjusted expected numbers of deaths were computed ${ }^{19}$ from the age specific death rates for men in China, 1973-5. ${ }^{170}$ The SMR was obtained by dividing the observed number of deaths by the expected number. Ninety five per cent confidence intervals (CI) for the SMR were calculated using Fisher's exact method when the observed number was less than eight and an approximate method when the observed number was more than eight. ${ }^{21}$ Tests for homogeneity and for trend of SMRs followed Breslow et al. ${ }^{22}$

\section{Results}

\section{ALL CAUSES OF DEATH}

The 6444 study subjects provided 80905 personyears of follow up. A greater proportion of miners $(82 \%)$ than above ground workers $(64 \%)$ were aged $30-49$ at the start of the study follow up. The above ground workers group had proportionally more younger $(<30)$ and older $(>50)$ members than the mine worker group (table 3 ). For the entire study group as of 31 December 1982, $5894(91.5 \%)$ were alive and $550(8.5 \%)$ were dead. Of the dead, 227 $(41 \%)$ had died of non-malignant respiratory disease, $111(20 \%)$ of malignant neoplasms including 31 $(6 \%)$ of lung cancer, $77(14 \%)$ of circulatory causes, and $135(25 \%)$ of other causes. Table 4 shows the crude death rates for underground and above ground workers for all and selected causes of death. Death rates were comparable for the two mines. Silicosis and silicotuberculosis were the major causes of death in both mines, being about eight times more frequent than lung cancer. The crude death rates for the

Table 3 Number (\%) of study cohort members by age in 1970, mine, and exposure status

\begin{tabular}{|c|c|c|c|c|c|c|c|c|c|c|c|c|}
\hline \multirow[b]{3}{*}{ Age (y) } & \multicolumn{4}{|c|}{ Longyan mine } & \multicolumn{4}{|c|}{ Taochong mine } & \multicolumn{4}{|c|}{ Two mines } \\
\hline & \multicolumn{2}{|c|}{ Exposed } & \multicolumn{2}{|c|}{ Unexposed } & \multicolumn{2}{|c|}{ Exposed } & \multicolumn{2}{|c|}{ Unexposed } & \multicolumn{2}{|c|}{ Exposed } & \multicolumn{2}{|c|}{ Unexposed } \\
\hline & No & $\%$ & No & $\%$ & No & $\%$ & No & $\%$ & No & $\%$ & No & $\%$ \\
\hline $\begin{array}{l}<20 \\
20- \\
30- \\
40- \\
50- \\
60- \\
\geqslant 70\end{array}$ & $\begin{array}{r}3 \\
557 \\
2308 \\
1662 \\
243 \\
45 \\
6\end{array}$ & $\begin{array}{r}0.1 \\
11.5 \\
47 \cdot 5 \\
34.5 \\
5.0 \\
0.9 \\
0.1\end{array}$ & $\begin{array}{r}5 \\
196 \\
364 \\
204 \\
99 \\
29 \\
0\end{array}$ & $\begin{array}{r}0.6 \\
21.9 \\
40.6 \\
22.7 \\
11.0 \\
3.2\end{array}$ & $\begin{array}{r}0 \\
99 \\
309 \\
141 \\
32 \\
1 \\
0\end{array}$ & $\begin{array}{r}- \\
17 \cdot 0 \\
53 \cdot 1 \\
24 \cdot 2 \\
5 \cdot 5 \\
0.2 \\
-\quad\end{array}$ & $\begin{array}{r}2 \\
31 \\
55 \\
39 \\
14 \\
0 \\
0\end{array}$ & $\begin{array}{r}1.4 \\
22.0 \\
39.0 \\
27 \cdot 7 \\
9.9 \\
-\end{array}$ & $\begin{array}{r}3 \\
656 \\
2617 \\
1830 \\
275 \\
46 \\
6\end{array}$ & $\begin{array}{r}0 \cdot 1 \\
12 \cdot 1 \\
48 \cdot 4 \\
33 \cdot 4 \\
5 \cdot 1 \\
0 \cdot 9 \\
0 \cdot 1\end{array}$ & $\begin{array}{r}7 \\
227 \\
419 \\
243 \\
113 \\
29 \\
0\end{array}$ & $\begin{array}{r}0.7 \\
21.9 \\
40.4 \\
23.4 \\
10.9 \\
2.8 \\
-\quad\end{array}$ \\
\hline Total & 4824 & $100 \cdot 0$ & 897 & $100 \cdot 0$ & 582 & $100 \cdot 0$ & 141 & $100 \cdot 0$ & 5406 & $100 \cdot 0$ & 1038 & $100 \cdot 0$ \\
\hline
\end{tabular}


Table 4 Number of cases and crude death rate $(C R)^{\star}$ for selected causes of death at two haematite mines, 1970-82

\begin{tabular}{|c|c|c|c|c|c|c|c|c|c|c|}
\hline \multirow[b]{2}{*}{ Mine } & \multirow{2}{*}{$\begin{array}{l}\text { No of } \\
\text { subjects }\end{array}$} & \multirow{2}{*}{$\begin{array}{l}\text { Person- } \\
\text { years }\end{array}$} & \multicolumn{2}{|c|}{ All causes } & \multicolumn{2}{|c|}{ All cancer } & \multicolumn{2}{|c|}{ Lung cancer } & \multicolumn{2}{|c|}{ Silicosis $\dagger$} \\
\hline & & & No & $C R$ & No & $C R$ & No & $C R$ & No & $C R$ \\
\hline $\begin{array}{l}\text { Underground workers: } \\
\text { Longyan } \\
\text { Taochong } \\
\text { Two mines } \\
\text { Above ground workers }\end{array}$ & $\begin{array}{r}4824 \\
582 \\
5406 \\
1038\end{array}$ & $\begin{array}{r}60491 \cdot 6 \\
7244 \cdot 7 \\
67736 \cdot 3 \\
13168 \cdot 8\end{array}$ & $\begin{array}{r}435 \\
55 \\
490 \\
60\end{array}$ & $\begin{array}{l}719 \cdot 1 \\
759 \cdot 2 \\
723 \cdot 4 \\
455 \cdot 6\end{array}$ & $\begin{array}{l}87 \\
11 \\
98 \\
13\end{array}$ & $\begin{array}{r}143 \cdot 8 \\
151 \cdot 8 \\
144 \cdot 7 \\
98 \cdot 7\end{array}$ & $\begin{array}{r}26 \\
3 \\
29 \\
2\end{array}$ & $\begin{array}{l}43 \cdot 0 \\
41 \cdot 4 \\
42 \cdot 8 \\
15 \cdot 2\end{array}$ & $\begin{array}{r}203 \\
23 \\
226 \\
0\end{array}$ & $\begin{array}{l}335 \cdot 6 \\
317 \cdot 5 \\
333 \cdot 6 \\
-\end{array}$ \\
\hline
\end{tabular}

*CR per $1 / 10^{5}$ person-years.

†Including silicotuberculosis.

selected causes of death for unexposed above ground workers were considerably lower than for underground miners.

\section{CANCER AMONG MINERS}

Pathological and radiological information was reviewed for $107(96 \%)$ of the 111 deaths from cancer. Nineteen $(61 \%)$ of the 31 cases of lung cancer, including the two cases among the unexposed, were based on a pathological diagnosis, although the cell type was available for only eight cases (three squamous cell, two undifferentiated, and three adenocarcinoma). Eleven cases (35\%) were based on radiological diagnosis and one on signs and symptoms (bloody hydrothorax followed shortly by death).

In table 5 SMRs are shown for all cancer and for selected cancer sites for the 5406 miners. All cancer mortality among miners was similar to that expected, based on Chinese national rates. No excesses were found for stomach, liver, or oesophageal cancer, which are more frequent causes of death than lung cancer in China. ${ }^{17} 20 \mathrm{~A}$ statistically significant excess of lung cancer (29 cases) was observed, SMR $=3.7$ $(p<0.05)$. For lymphosarcoma there were four cases (cause specific death rate from China not available); for leukaemia the SMR $=1.5(n=3)$ and for other cancer sites SMRs were not calculated due to small numbers.

Mortality results for lung cancer are presented in table 6 by mine, by level of exposure, and by first employment before and after the introduction of ventilation and wet drilling. The risk of lung cancer among unexposed workers was not raised, SMR $=1 \cdot 2$, although the result was based on only two cases. Among all exposed miners, the risk of lung cancer was raised among Longyan (SMR $=3 \cdot 6)$ and Taochong (SMR $=4 \cdot 2$ ) mine workers and rose for both mines combined with level of exposure for low $(\mathrm{SMR}=2 \cdot 6)$, medium $(\mathrm{SMR}=2 \cdot 6)$, and heavily $(S M R=4.2)$ exposed miners. When the trend in risk is examined among the unexposed, low, medium, and heavily exposed, the increase in risk with exposure category was of borderline significance $\left(\chi^{2}=1.93, p \approx 0.05\right)$. When the trend was examined among the low, medium, and heavily exposed, ignoring the unexposed, the increase in risk with level of exposure was only moderate and statistically not significant $\left(\chi^{2}=1.06, p=0.29\right)$. When considering the risks associated with changes in ventilation, the numbers of cases are small, particularly among those initially employed after the introduction of ventilation. The risk for workers initially employed before the introduction of ventilation, $S M R=4.8$, is higher than the risk for those employed after its introduction, $S M R=2 \cdot 4$, although the difference was not statistically significant $(p=0.08)$. For mine workers in jobs with heavy dust exposure, the SMRs are $4.8(\mathrm{p}<0.05)$ and $3.5(\mathrm{p}<0.05)$, respectively, for those ever and never employed before the introduction of ventilation. Environmental monitoring results for Longyan mine were available for dust, radon, radon daughters, and $\mathrm{BaP}$. These results with the associated risks of lung cancer by exposure category are presented in table 2. Exposure levels for radon and radon daughters, but not for $\mathrm{BaP}$, were higher in high dust level jobs.

Table 7 presents the lung cancer mortality rates with respect to the presence of other pulmonary diseases. Silicotics had a more than fivefold risk of

Table 5 Number of deaths and SMRs for cancer by site at two haematite mines, 1970-83

\begin{tabular}{|c|c|c|c|c|c|c|}
\hline \multirow[b]{2}{*}{ Tumour site (ICD-9) } & \multirow{2}{*}{$\frac{\text { Longyan }}{\text { No of deaths }}$} & \multirow{2}{*}{$\frac{\text { Taochong }}{\text { No of deaths }}$} & \multicolumn{4}{|c|}{ Two mines } \\
\hline & & & Obs & $\operatorname{Exp}$ & $S M R^{\star}$ & $95 \% C I$ \\
\hline $\begin{array}{l}\text { All cancer }(140-239) \\
\text { Lung }(162) \\
\text { Stomach }(151) \\
\text { Liver }(155) \\
\text { Oesphagus (150) }\end{array}$ & $\begin{array}{r}87 \\
26 \\
16 \\
15 \\
9\end{array}$ & $\begin{array}{r}11 \\
3 \\
2 \\
2 \\
2\end{array}$ & $\begin{array}{l}98 \\
29 \\
18 \\
17 \\
11\end{array}$ & $\begin{array}{r}89 \cdot 88 \\
7 \cdot 89 \\
22 \cdot 33 \\
22 \cdot 48 \\
18 \cdot 13\end{array}$ & $\begin{array}{l}1 \cdot 1 \\
3 \cdot 7 \\
0 \cdot 8 \\
0 \cdot 8 \\
0 \cdot 6\end{array}$ & $\begin{array}{l}0 \cdot 9,1 \cdot 3 \\
2 \cdot 5,5 \cdot 3 \\
0 \cdot 5,1 \cdot 3 \\
0 \cdot 4,1 \cdot 2 \\
0 \cdot 3,1 \cdot 1\end{array}$ \\
\hline
\end{tabular}


Table 6 SMRs for lung cancer at two haematite mines, 1970-82

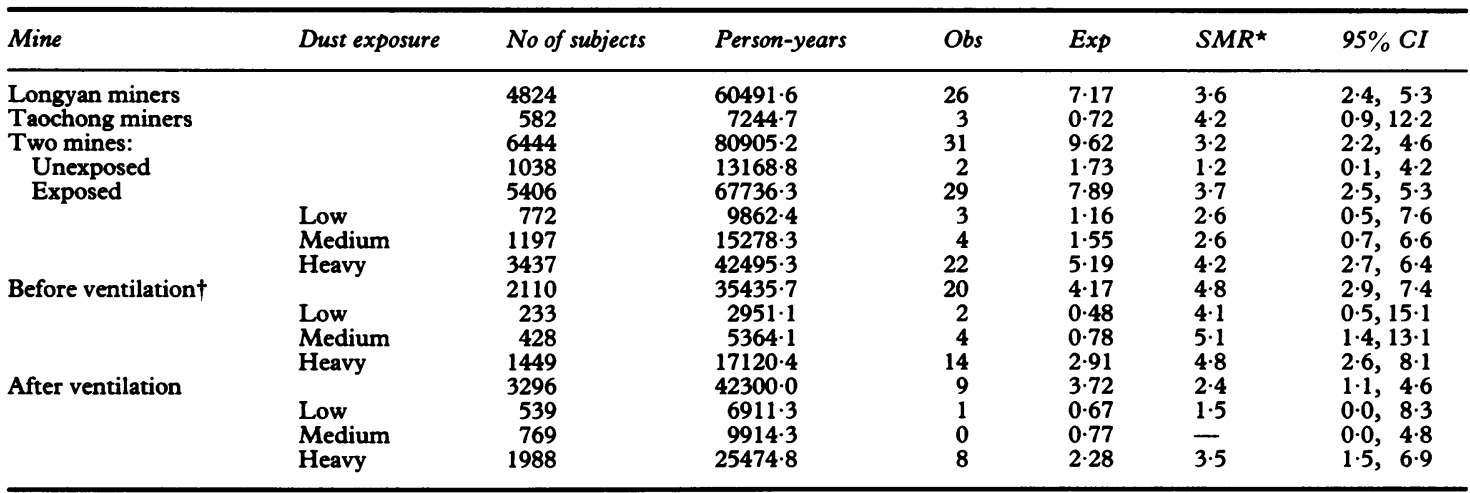

*SMR based on nationwide male population in China, 1973-5, by age.

+ Workers with first exposure underground before the introduction of ventilation and wet drilling, which were introduced in Longyan mine in 1955 and in Taochong mine in 1963.

lung cancer $(S M R=5.3, p<0.05)$ although, among non-silicotic subjects, the risk for lung cancer was also significantly raised $(S M R=2 \cdot 9$, $\mathrm{p}<0.05)$. The difference in SMRs between silicotic and non-silicotic subjects was not statistically significant. Silicotic subjects with tuberculosis were at high risk for lung cancer $(S M R=6.6 ; p<0.05)$. For silicotic subjects with heavy dust exposure, which comprised almost all of them the $S M R=5 \cdot 0$. Among miners without silicosis, the risk by level of dust was $S M R=1.2$ for the unexposed, SMR $=2.8$ for low, SMR $=1.5$ for medium, and SMR $=3.6$ for heavily exposed workers. The trend was not statistically significant $\left(\chi^{2}=1 \cdot 5, p=0 \cdot 14\right)$.

Among all cohort members, $4830(75 \%)$ were current smokers, $1426(22 \%)$ had never smoked, and $188(3 \%)$ were ex-smokers (table 8). Among exposed miners who never smoked, one death from lung cancer was observed whereas 1.7 were expected based on national rates. Among current smokers, the SMRs by level of dust exposure were 1.6 (based on two cases), 2.4 (based on two cases), and 3.3 and 4.9, respectively, for unexposed, low, medium, and heavily exposed workers. The trend was of marginal statistical significance $\left(\chi^{2}=1 \cdot 89, \mathrm{p}=0.06\right)$.

\section{Discussion}

This study of mortality at two haematite mines in China shows an excess risk for non-malignant respiratory disease and a 3.7-fold excess for lung cancer among workers employed underground at the mines. Death due to non-malignant respiratory disease, particularly pneumoconiosis and pneumoconiosis with tuberculosis, was a major health hazard in these mines, being the cause of $46 \%$ of deaths. It was only possible in the present analysis to assess crude rates for death due to silicosis. Further detailed analyses are being planned.

The risks for total cancer and selected cancers other than lung cancer were not raised in the study group. The excess of lung cancer was limited to those working underground and was higher among those ever employed underground in the mines before the introduction of ventilation. Overall the risk for lung

Table 7 SMRs for lung cancer by history of lung disease at two haematite mines, 1970-82

\begin{tabular}{|c|c|c|c|c|c|c|c|}
\hline Lung disease & Dust exposure & No of subjects & Person-years & Obs & $\operatorname{Exp}$ & $S M R^{\star}$ & $95 \% C I$ \\
\hline \multirow[t]{3}{*}{ Silicosis: } & & 1335 & $15543 \cdot 1$ & 14 & $2 \cdot 67$ & $5 \cdot 3$ & $2 \cdot 9,8 \cdot 8$ \\
\hline & Low & 32 & $391 \cdot 4$ & $\mathbf{0}$ & $0 \cdot 07$ & - & \\
\hline & Medium & $\begin{array}{r}77 \\
1226\end{array}$ & $\begin{array}{r}898.4 \\
53.3\end{array}$ & 2 & 0.18 & $11 \cdot 1$ & $\begin{array}{l}1 \cdot 3,40 \cdot 1 \\
2 \cdot 6\end{array}$ \\
\hline \multirow[t]{3}{*}{ Non-silicosis: } & Heavy & $\begin{array}{l}1220 \\
4071\end{array}$ & $\begin{array}{l}14253 \cdot 3 \\
52193 \cdot 3\end{array}$ & $\begin{array}{l}12 \\
15\end{array}$ & $\begin{array}{l}2 \cdot 41 \\
5 \cdot 23\end{array}$ & $\begin{array}{l}5.0 \\
2.9\end{array}$ & $\begin{array}{ll}2 \cdot 0, & 8 \cdot 7 \\
1 \cdot 6, & 4 \cdot 7\end{array}$ \\
\hline & Low & 740 & $9471 \cdot 0$ & 3 & 1.09 & $2 \cdot 8$ & $0.6,8.0$ \\
\hline & Medium & 1120 & $\begin{array}{l}14380 \cdot 1 \\
28342 \cdot 0\end{array}$ & $\begin{array}{r}2 \\
10\end{array}$ & $\begin{array}{l}1.37 \\
2.77\end{array}$ & 3.6 & $\begin{array}{ll}0.2, & 5.3 \\
1.7 & 6.6\end{array}$ \\
\hline \multirow{2}{*}{\multicolumn{2}{|c|}{ Tuberculosis }} & 567 & $6102 \cdot 7$ & 7 & 1.08 & $6 \cdot 5$ & $2 \cdot 6,13 \cdot 4$ \\
\hline & 4839 & 61633.7 & 22 & 6.82 & $3 \cdot 2$ & $2 \cdot 0,4.9$ \\
\hline & & 560 & $6032 \cdot 9$ & 7 & 1.07 & $6 \cdot 6$ & $\cdot 6,13 \cdot 5$ \\
\hline \multicolumn{2}{|c|}{ Siliosis with non-tuberculosis } & 775 & $9510 \cdot 2$ & 7 & 1.60 & $4 \cdot 4$ & $1.8,9.0$ \\
\hline \multirow{2}{*}{\multicolumn{2}{|c|}{$\begin{array}{l}\text { Non-silicosis with tuberculosis } \\
\text { Non-silicosis with non-tuberculosis }\end{array}$}} & & $69 \cdot 8$ & 0 & 0.0 & 一 & \\
\hline & & 4064 & $52123 \cdot 8$ & 15 & $5 \cdot 22$ & $2 \cdot 9$ & $1 \cdot 6,4 \cdot 7$ \\
\hline
\end{tabular}

*SMR based on nationwide male population in China, 1973-5, by age. 
Table 8 SMRs for lung cancer by history of cigarette smoking at two haematite mines, 1970-82

\begin{tabular}{|c|c|c|c|c|c|c|c|}
\hline & Dust exposure & No of subjects & Person-years & Obs & $\operatorname{Exp}$ & $S M R^{\star}$ & $95 \% C I$ \\
\hline \multicolumn{8}{|l|}{ All workers: } \\
\hline Never smoked & & 1426 & $17721 \cdot 7$ & 1 & $2 \cdot 14$ & 0.5 & $0.0,2.6$ \\
\hline Current smoker & & 4830 & $60870 \cdot 7$ & 27 & $7 \cdot 13$ & $3 \cdot 8$ & $2 \cdot 5,5 \cdot 5$ \\
\hline Unexposed $\dagger$ & & 745 & $9439 \cdot 9$ & 2 & 1.22 & 1.6 & \\
\hline \multicolumn{8}{|l|}{ Exposed: } \\
\hline \multirow{5}{*}{$\begin{array}{l}\text { Never smoked } \\
\text { Current smoker } \dagger\end{array}$} & & 1173 & $14505 \cdot 3$ & 1 & $1 \cdot 70$ & 0.6 & $0.0,3.3$ \\
\hline & & 4085 & $51430 \cdot 8$ & 25 & 5.90 & $4 \cdot 2$ & $2 \cdot 7,6 \cdot 3$ \\
\hline & Low & 574 & $7350 \cdot 6$ & 2 & 0.85 & $2 \cdot 4$ & $0.3,8.5$ \\
\hline & Medium & 937 & $11957 \cdot 8$ & 4 & 1.20 & $3 \cdot 3$ & $0.9,8.5$ \\
\hline & Heavy & 2574 & $32122 \cdot 3$ & 19 & 3.85 & 4.9 & $3 \cdot 0,7 \cdot 7$ \\
\hline \multicolumn{8}{|l|}{ Ventilation: $†$} \\
\hline Before & & 1555 & $18903 \cdot 7$ & 17 & 3.07 & $5 \cdot 5$ & $3 \cdot 2,8 \cdot 7$ \\
\hline After & & 2530 & $32527 \cdot 0$ & 8 & $2 \cdot 84$ & $2 \cdot 8$ & $1 \cdot 2,5 \cdot 6$ \\
\hline \multicolumn{8}{|l|}{ Silicosis: $†$} \\
\hline Yes & & 962 & $11357 \cdot 1$ & 13 & 1.93 & $6 \cdot 7$ & $3 \cdot 6,11 \cdot 5$ \\
\hline No & & 3123 & 40073.7 & 12 & 3.98 & $3 \cdot 0$ & $1 \cdot 6,5 \cdot 3$ \\
\hline \multicolumn{8}{|l|}{ Tuberculosis: $\dagger$} \\
\hline Yes & & 389 & $4234 \cdot 7$ & 7 & $0 \cdot 75$ & $9 \cdot 3$ & $3 \cdot 8,19 \cdot 2$ \\
\hline No & & 3696 & 47196.0 & 18 & $5 \cdot 16$ & 3.5 & $2 \cdot 1, \quad 5 \cdot 5$ \\
\hline
\end{tabular}

*SMR based on nationwide male population in China, 1973-5, by age.

†Analysis performed in current smoking group.

cancer also increased with level of dust exposure from low to heavy, although it was only a moderate increase in risk. This may be attributable to small numbers, particularly for the low and medium exposed groups, or to the failure of job title to differentiate between dust exposure groups clearly. It is also important that workers who became ill while working in heavily exposed jobs may have been moved to other lower exposed duties. The observed association was probably not solely due to tobacco use since the risk increased with level of exposure, even when the analysis was restricted to smokers. Radford and Renard found an excess risk for lung cancer in Swedish iron ore miners among both smokers and non-smokers. ${ }^{6}$ Owing to the limited number of non-smokers in this study in China, and the finding of only one case among non-smokers, we could not evaluate this result.

The presence of lung cancer in this study may be due to exposures other than dust, in particular to radon gas and radon daughters. Environmental measurements from the Longyan mine indicated that dust levels seemed to parallel the concentration of radon and radon daughters, making it impossible to evaluate the independent effect of these exposures. In both mines iron oxide and silica were the major components of airborne and settled dusts. Current concentrations of radon and radon daughters occurred at levels about fourfold the acceptable limit for inhabitants of China. Undoubtedly levels for all exposures had been considerably higher in the past, particularly before the introduction of ventilation controls. Radford and Renard found a fourfold excess risk of lung cancer among Swedish iron miners exposed to radon daughter concentrations close to the accepted occupational limit (4WLM/ year), with a clear dose response relation. ${ }^{6}$ In addition, other studies of iron miners and of uranium miners have established that exposure to radon gas $\stackrel{9}{\mathcal{T}}$ increases the risk of lung cancer. ${ }^{23}$ Recently, Mur reported findings from a proportional mortality study of French iron ore miners employed in the Lorraine basin. ${ }^{9}$ Geologically, he reports, this area was formed from sediments with no detectable radioactivity in the mines. Nevertheless, excesses of lung cancer of similar magnitude to that of the present study were found. Although radioactive decay products of uranium present a significant risk $\overline{\bar{O}}$ of lung cancer, it is essentially difficult to sort out independent and combined effects of the multiple disease causing agents found in most iron and other types of mines.

Silicotic subjects, particularly those with silicotuberculosis, were at somewhat higher risk of lung cancer than were non-silicotic subjects. The presence of these diseases may increase the risk of $\delta$ developing lung cancer as has been suggested by limited evidence from studies of silicotic subjects who had been employed as miners, quarry workers, foundry workers, ceramic workers, granite workers, and stone cutters. ${ }^{912}$

In this study an excess risk for lung cancer was $\sigma$ shown to be associated with underground employ- N ment in haematite mines. Those with heavier dust $\underset{\mathrm{N}}{ }$ exposure, those who had worked before the introduction of ventilation and wet drilling dust control measures, and those who had non-malignant respiratory diseases appeared to be at excess risk. Although the differences in risk were pronounced, tests for homogeneity of risk of lung cancer or for trend in risk of lung cancer often did not reach the established level of statistical significance $(p<0.05)$. Statistical differences in risk for lung cancer may, to some extent, have been attenuated by competing risk-that is, death due to silicosis, although small numbers of study subjects in some 
comparison groups undoubtedly decreased the power of these tests.

In summary, the present study has shown a clear excess risk for death due to silicosis and to lung cancer in two Chinese haematite mines. The risk for lung cancer could not be attributed solely to tobacco use. Risk was associated with working conditions underground, especially with exposure to dust, radon, and radon daughters, and with the presence of non-malignant respiratory disease.

We are most grateful to Longyan Iron-Steel Company and Taochong Iron Mine for their collaboration and for making significant contributions to this study and to Dr Z H Chang of the Seventh Research Institute Ministry of Nuclear Industry and to Dr R J Han of the Institute of Labour Hygiene, Benxi Iron-Steel Company, for their help.

1 Faulds JS, Stewart MJ. Carcinoma of the lung in haematite miners. Journal of Pathology and Bacteriology. 1956;72: 353-66.

2 Boyd JT, Doll R, Faulds JS. et al. Cancer of the lung in iron ore (haematite) miners. Br J Ind Med 1970;27:97-105.

3 Duggan MJ, Soilleux RJ, Strong JC, et al. The exposure of United Kingdom miners to radon. $B r J$ Ind Med 1970;27: 106-9.

4 St Clair Rennard KG. Respiratory cancer mortality in an iron ore mine in northern Sweden. Ambio 1974;2:67-9.

5 Jorgensen HS. Lung cancer among underground workers in the iron ore mine of Kiruna based on thirty years of observation. Ann Acad Med Singapore 1984;13:371-7.

6 Radford EP, St Clair Rennard KG. Lung cancer in Swedish iron miners exposed to low doses of radon daughters. N Engl J Med 1984;310:1485-94.

7 Pham QT, Gaertner M, Mur JM, et al. Incidence of lung cancer among iron miners. Eur J Respir Dis 1983;64:534-40.

8 Edling C, Axelson $\mathrm{O}$. Quantitative aspects of radon daughter exposure and lung cancer in underground miners. $\mathrm{Br} J$ Ind Med 1983;40:182-7.

9 Mur JM, Meyer-Bisch C, Pham QT, et al. Risk of lung cancer among iron ore miners. A proportional mortality study of 1075 deceased miners in Lorraine, France. $J$ Occup Med 1987;29:762-8.

10 Gurevich MA. Primary cancer of the lung in iron ore miners. Sov Med 1967;30:71-6.

11 International Agency For Research on Cancer. Monographs on the evaluation of the carcinogenic risk of chemicals to humans. Vol 1. Lyon: IARC, 1972:29-39.

12 International Agency For Research on Cancer. Monographs on the evaluation of the carcinogenic risk of chemicals to humans. Vol 42. Silica and silicates. Lyon: IARC, 1987:96-111.

13 Lawler AB, Mandel JS, Schuman IM, et al. A retrospective cohort mortality study of iron ore (haematite) miners in Minnesota. J Occup Med 1985;27:507-17.

14 Kinlen LJ, Willows AN. Decline in the lung cancer hazard: a prospective study of the mortality of iron miners in Cumbria. Br J Ind Med 1988;45:219-24.

15 International Register of Potentially Toxic Chemicals. Instructions for the selection and presentation of data for the international register of potentially toxic chemicals with sixty illustrative chemical data profiles. Beijing: Sheng $\mathrm{Li}, 1979$. (Translation.)

16 Ministry of Public Health PRC. Regulation of radiation protection. Beijing: Agency of the National Criteria (GBJ), 1974: 8-74.

17 Ministry of Public Health PRC. Investigation of death due to malignant tumor in China. Beijing: People's Medical Publishing House, 1979.

18 World Health Organisation. International classification of diseases. 9th rev. Geneva: WHO, 1977.

19 National Cancer Institute. $O / E$ system. Observed versus expected events. Users guide-version 3.3. Epidemiology and biostatistics program. Bethesda, Maryland: National Cancer Institute, 1987.

$20 \mathrm{Li} \mathrm{JY,} \mathrm{Liu} \mathrm{BQ,} \mathrm{Li} \mathrm{GY,} \mathrm{et} \mathrm{al.} \mathrm{Atlas} \mathrm{of} \mathrm{cancer} \mathrm{mortality} \mathrm{in} \mathrm{the}$ People's Republic of China. Beijing: China Map Press, 1979.

21 Rothman KJ, Boice JD. Epidemiologic analysis with a programmable calculator. Washington: US Government Printing Office, 1979. (NIH publ No 79-1649.)

22 Breslow NE, Lubin JH, Marek P, et al. Multiplicative models and cohort analysis. Journal of the American Statistical Association 1983;78:1-12.

23 National Research Council. Health risks of radon and other internally deposited alpha-emitters, BEIR IV. Washington: National Academy Press, 1988.

Accepted 3 April 1989 